UDC $94(5)$

DOI: $10.24044 / \mathrm{sph} .2017 .4 .5$

\title{
THE FOUNDING AND DEVELOPMENT PROCESS OF FREE ECONOMIC INDUSTRIAL ZONES OF UZBEKISTAN (in case "Navoi" free economic industrial zone)
}

U. O. Narzullaev

\author{
Independent researcher, \\ e-mail: umidjon-ndpi@mail.ru, \\ Navoi State Pedagogical Institute, \\ Navoi, Uzbekistan
}

\begin{abstract}
The article summarizes the socio-economic development of Uzbekistan on the example of the Navoi region in the period of independence. Special attention also paid to the problems of development of the Free Industrial Economic Zone "Navoi" in the conditions of economic reform. The legislative basis for the creation and development of "Navoi" free industrial economic zone and other similar objects are considered. Actions of the government headed by the President Sh. Mirziyoyev for the improvement of the activities of the "Navoi" free industrial economic zone in the framework of The Strategy of Actions for the development of the Republic of Uzbekistan along five priority areas in 2017-2021 are analyzed.

Keywords: Uzbekistan; economy; free economic industrial zones; free economic industrial zones of Uzbekistan; Navoi region; Navoiy Airport; Navoi cargo center; International Logistic of Navoi.
\end{abstract}

Today the authority of Uzbekistan is being strengthened in the international arena more and more. Leading companies of many countries have a great interest in direct investments. Uzbekistan together with the developed countries and authoritative international organizations is implementing a number of promising projects. It should be noted that in Uzbekistan a special attention is paid to the development and support of small business and private entrepreneurship, attraction of the investments in all sectors of the economy.

According to the Decree of the President of Uzbekistan, Free Industrial Economic Zone (FIEZ) have been created in Navoi Province of Uzbekistan with special conditions for foreign investments.

FIEZ is designed to promote a wide range of high-tech and internationally competitive production using modern high-efficiency equipment, technological lines and units, as well as latest innovations. The operation period of FIEZ is 30 years with possible prolongation.

Business entities registered in FIEZ will enjoy exceptional customs, currency and tax regulations, simplified procedure for entry, stay and obtaining of work permit for nonresident citizens.

The Zone will be located at a distance of 800 meters from the highway E-40, $1,8 \mathrm{~km}$ from the cargo terminal of Navoi Airport, connected to international railway routes towards countries of Europe (via Russia), South Asia (via China), Middle East and the Gulf (via Iran). The distance to the nearest water and gas distribution centers is $800 \mathrm{~m}$, electrical station $-8 \mathrm{~km}$. Along with this, in August 2010 Hanging Group (the parent of Korean Air) opened a new cargo terminal at Navoi Airport. Above-mentioned logistic system organizes delivery from the manufacture to the consumer in other words it forms conveying loads by means of different transportations [2, p. 34].

Taking into consideration that organization of free economic zones has important significance in developing country's economics the Order of the President of Uzbekistan about "Organizing free industrial economic zone in Navoi region" was adopted in 2 December of 2008. According to this order 
it has begun carrying out wide social economic reforms in the region [1, p. 3].

It is well known that in Central Asia, especially in Uzbekistan there is no way to any seas. We can go to sea only passing at least the borders of two countries. The logistic system of "Navoi" airport was organized for solving this problem. Situating in the most important crossroads of rail and airways the Navoi city's airport connects the Southeastern countries of Asia to the countries of Central and South Asia, Middle and South Europe. This in turn has a great importance in the reconstructing of the new Great Silk Road, which tied Europe, India, China, and South-Eastern Asia. In 2012, it has already begun international regular movements to Seoul, Milan, Brussels, Bangkok, Deli, Mumbai, Shanxi, Frankfort, Dubai, Istanbul, Tel-Aviv.

Moreover, the "Korean Air" company taking an active participation in organization of "Navoi free industrial-economic zone" and in developing of "The International logistic Center". In 2009, the company presented two load-lifting aircrafts "A 300-600 F". The capability of the center grown and all the ways to the load markets in the world was opened for it. As the new airbuses could carry 40 tons of load and pass 7 thousand $\mathrm{km}$ in one rising. In 2009 about 8,5 thousand tons of load were carried out in the international directions. This activity was raised till 44,3 thousand tones [3, p. 46.] in 2010, till 102,1 thousand in 2011, and 134 tons in 2012.

The main aim of this - creating perfect conditions, increasing industrialization and manufacturing power of Navoi region, developing transport, transit and social infrastructure; to attract foreign investments, first of all direct investments to create perfect conditions for founding manufacturing companies which have modern technology and which can provide with the demandable products in the world market; opening new work places training and preparing wellskilled workers, engineers, housekeepers and governors.
From the time when Navoi free industrial economic zone was founded and began its activities there were a lot of proposes about entering huge amount of investments from the biggest firms and companies and there were invited for future projects. Moreover, the leaders of our country paid attention to the ecological situation of the region, and produce ecologically pure products.

Oliy Majlis of the Republic of Uzbekistan on 26 May 2009 adopted and officially forced on 24 of September, in 2009, the law about "About some additions to the law about free industrial zones" [5, p. 1]. The adoption of the law contributed to reform country's financial system and encouraged direct investments in global financial economic crises condition.

During the past periods, the interest of foreign companies to Navoi FIEZ is increased. At the same time, more than 20 projects are working out in the coexistence with South Korea, China, Singapore, India, and UAE and with the other countries.

We can say that during 2010-2011 it was pointed to start realizing 17 projects according to above-mentioned law. In twelve of them had finished construction and installation works, in 10 of these projects have already begun producing products. For example, during 2011 there was produced goods for 35,9 milliard sums and goods for 195,2 thousand dollars was export. In a near future, the number of projects may increase. There are many opportunities to attract foreign investments for $40-50$ projects, which requires approximately 900 million dollars. If all entities will start functioning they would produce exportable products in an amount of 1,5 milliard dollars.

Based on the experience in organization of free industrial zones Uzbekistan is able organize such zones in other regions. Nowadays, for this aim republic is on the way to develop free industrial zones such as "Angren", "Jizzax".

On September 2, 2016, Islam Karimov, President of Uzbekistan, passed away and the 
Prime Minister Shavkat Mirziyoyev became the acting president. In his speech on September 8, 2016 at a joint meeting of the Parliament of Uzbekistan, Mirziyoyev called his main task as the continuation of the democratic reforms and transformations in the political, economic, and social spheres, and ensuring the rights and freedoms of citizens. He also determined one of his most important priorities to be strengthening cooperation with foreign countries.

On January 122017 President of the Republic of Uzbekistan Shavkat Mirziyoev signed a Decree "On the establishment of free economic zones "Urgut", "Gijduvan", "Kokand" and "Khazarasp" [7, p. 1] and on 3 May 2017 signed a Decree "On creation of free economic zones Nukus-pharm, Zominpharm, Kosonsoy-pharm, Sirdaryo-pharm, Baisun-pharm, Bustonliq-pharm and Parkentpharm" [8, p. 1].

Shavkat Mirziyoyev ordered to develop a programme on creating industrial plantation and list of concrete types of medical plants, recommended for production with further deep processing and production of medicaments and dietary supplements in the territory of new free economic zones. The decree said that modern production capacities on processing medical herbs and production of medicaments and medical products, auxiliary and packaging materials will be created in new zones. This will help to deepen localization of production of pharmaceutical products based on local medical herbs and materials. Economic zones created for 30 years with opportunity to extend it. Special tax, customs and currency regimes will be applied in new zones. [9, p. 1]

The Strategy of actions on five priority areas of development of the Republic of Uzbekistan in 2017-2021 [10, p. 1] outlines a number of tasks on strengthening macroeconomic stability, actively attracting investment in the economy and regions, especially foreign ones, creation of favorable conditions for development of private entrepreneurship on the basis of privatized state facilities, socio-economic development of districts and cities. Important side in this direction is the ongoing activity on improving the efficiency of free economic zones, technoparks and small industrial zones, creation of new ones. In accordance with the "Decree on additional measures of activating and expanding free economic zones" of October 26, 2016, conditions that are more favorable have been created for this work. Currently, there are 14 free economic zones in the country. 62 projects worth 486 million dollars are realized in "Navoi", "Angren", "Jizzakh", "Urgut", "Gijduvan", "Kokand" and "Khazarasp" FEZ, more than 4,6 thousand workplaces are created $[11$, p. 1].

\section{Bibliography}

1. Creation special economic zones in the Republic of Uzbekistan. (Analytical report) Development program of UN, 2008. - P. 3.

2. The newspaper of Oliy Majlis of the Republic of Uzbekistan. Tashkent. 1996. Number 3. - P. 34.

3. Karimov I. A. Our main aim is to increase our country's development and stability of our people much more. - Tashkent : Uzbekistan, 2010. - P. 46.

4. The resolution of Ministry of Legal offices about "The ways of organization "Navoi" free industrial economic zone's activities"// the collection of the resolutions of the Republic of Uzbekistan. № 4. P. 42-44.

5. The legal guarantee of free industrial zone's activity // The word of the people. 18 August, 2009.

6. Mirzokhid Rakhimov. New Priorities of Uzbekistan. Journal of international affairs. Columbia University. Apr 17, $2017 \quad$ // https://jia.sipa.columbia.edu/online-articles/newpriorities-uzbekistan (26.10.2017).

7. http://prezident.uz/ru/lists/view/182 (26.06.2017)

8. http://uza.uz/oz/documents/nukus-farm-zominfarm-kosonsoy-farm-sirdarye-farm-boysun-far04-05-2017?sphrase_id=2758257 (09.08.2017).

9. https://www.uzdaily.com/articles-id-39280.htm (08.09.2017).

10. Decree of the President of the Republic of Uzbekistan "On the Strategy of Actions for the Further Development of the Republic of Uzbekistan”. 7 February 2017.

11. http://www.uzbekistan.de/en/nachrichten/nachrich ten/issues-development-free-economic-zonesand-small-industrial-zones-are (14.09.2017). 


\section{Bibliography}

1. Creation special economic zones in the Republic of Uzbekistan. (Analytical report) Development program of UN, 2008. - P. 3.

2. The newspaper of Oliy Majlis of the Republic of Uzbekistan. Tashkent. 1996. Number 3. - P. 34.

3. Karimov I. A. Our main aim is to increase our country's development and stability of our people much more. - Tashkent : Uzbekistan, 2010. - P. 46.

4. The resolution of Ministry of Legal offices about "The ways of organization "Navoi" free industrial economic zone's activities"// the collection of the resolutions of the Republic of Uzbekistan. № 4. P. 42-44.

5. The legal guarantee of free industrial zone's activity // The word of the people. 18 August, 2009.

6. Mirzokhid Rakhimov. New Priorities of Uzbekistan. Journal of international affairs. Columbia
University. Apr 17, $2017 \quad$ // https://jia.sipa.columbia.edu/online-articles/newpriorities-uzbekistan (26.10.2017).

7. http://prezident.uz/ru/lists/view/182 (26.06.2017).

8. http://uza.uz/oz/documents/nukus-farm-zominfarm-kosonsoy-farm-sirdarye-farm-boysun-far04-05-2017?sphrase_id=2758257 (09.08.2017).

9. https://www.uzdaily.com/articles-id-39280.htm (08.09.2017).

10. Decree of the President of the Republic of Uzbekistan "On the Strategy of Actions for the Further Development of the Republic of Uzbekistan". 7 February 2017.

11. http://www.uzbekistan.de/en/nachrichten/nachrich ten/issues-development-free-economic-zonesand-small-industrial-zones-are (14.09.2017).

(C) Narzullaev U. O., 2017. 